\title{
sciendo
}

CIVIL AND ENVIRONMENTAL ENGINEERING REPORTS

E-ISSN 2450-8594

CEER 2019; 29 (2): 031-040

DOI: $10.2478 /$ ceer-2019-0014

Original Research Article

\section{MICROSCOPIC EVALUATION OF THE MANHOLES IN SELECTED SEWERAGE PRESSURE SYSTEM}

\author{
Bartosz BOGUSŁAWSKI ${ }^{1}$, Anna GŁOWACKA ${ }^{1}$, Teresa RUCIŃSKA ${ }^{2}$ \\ West Pomeranian University of Technology in Szczecin, Szczecin, Poland
}

\begin{abstract}
The aim of the research was to determine changes in the elemental composition of concrete under the influence of exposure to hydrogen sulphide in the existing sewage system. The system operator pointed to significant problems with odours in this system. The research included a fragment of the pressure sewage system. The concentration of gases: hydrogen sulphide, ammonia and methane was measured in selected wells. High concentrations of hydrogen sulphide (over $200 \mathrm{ppm}$ ) were recorded in the studies. Concrete samples were taken from the internal walls of the well for testing. The samples were used for a microscopic analysis of their composition, using an electron microscope with an EDS attachment. Also, concrete samples from a new sewage well were tested to compare their elemental composition. Gas measurements confirmed the problem of odors, while the analysis of the elemental composition showed a significant proportion of sulphur (from $7.53 \%$ to $42.9 \%$ ) on the surface of the well compared to the reference sample ( $0 \%$ ).

Keywords: hydrogen sulfide, biocorrosion, pressure sewage system, sulfate attack on concret
\end{abstract}

\footnotetext{
${ }^{1}$ Corresponding author: Department of Sanitary Engineering West Pomeranian University of Technology in Szczecin, Piastów st 50, 70-311 Szczecin, Poland

${ }^{2}$ Corresponding author: Department of Building Physics and Building Materials West Pomeranian University of Technology in Szczecin, Piastów st 50, 70-311 Szczecin, Poland
} 


\section{INTRODUCTION}

Biocorrosion is a well-known and frequently occurring problem of many sewage systems in Poland and abroad. Restricted water use and local water recycling results in increased hydraulic retention time of sewage in sewers [1]. The German standard DIN EN 1671[2] states that the sewage retention time in the pumping station should be maximum 4 hours. Meanwhile, according to PN-EN 1671[3] the total time of sewage retention in the sewage system (from the place of its origin to the sewage treatment plant) should not exceed 8 hours. In practice, retention times can reach 95.7 hours [4] and even 595h [5], in individual delivery sections. Long retention times in the system result in dissolved oxygen depletion and anaerobic conditions. Anaerobic transformations in the biofilm generate gases hydrogen sulphide and ammonia. Hydrogen sulphide diffuses from the biofilm into the wastewater, with which it is further transported to the expansion well or pumping station, where it is released into the atomsphere. It then dissolves in moisture on the internal walls and is oxidized by bacteria oxidizing sulphur to sulphuric acid, which causes sulphate corrosion of the concrete elements of the system.

Conditions under which sulfate corrosion occurs [6] :

- low oxygen concentration, below $1 \mathrm{mg} / \mathrm{l}$ or anaerobic conditions,

- dampness in the walls of the well and pumping station,

- wastewater $\mathrm{pH}<8$,

- time of sewage retention in the pressure conduit longer than $0.5 \mathrm{~h}$,

- concrete $\mathrm{pH}$ below 9 [7].

The chemical composition of cement determines the resistance of concrete to corrosion. Concrete corrosion is a degradation of the cement mortar that forms it [8]. Tabel 1 shows the content of oxides in Portland cement.

Table 1. Approximate content limits of oxides in Portland cement [9]

\begin{tabular}{|l|c|}
\hline Type of oxide & content, \% \\
\hline $\mathrm{CaO}$ & $60-67$ \\
\hline $\mathrm{SiO}_{2}$ & $17-25$ \\
\hline $\mathrm{Al}_{2} \mathrm{O}_{3}$ & $3-8$ \\
\hline $\mathrm{Fe}_{2} \mathrm{O}_{3}$ & $0,5-6,0$ \\
\hline $\mathrm{MgO}$ & $0,5-4,0$ \\
\hline $\mathrm{Alkalia}\left(\right.$ jako $\left.\mathrm{Na}_{2} \mathrm{O}\right)$ & $0,3-1,2$ \\
\hline $\mathrm{SO}_{3}$ & $2,0-3,5$ \\
\hline
\end{tabular}


According to PN-EN 197-1[10] cement, depending on the type, may contain up to $4.5 \%$ sulphates. Occasionally, the source of sulphate in concrete may be the sulphur compounds present in aggregate (e.g. gypsum or pyrite). Pyrite may oxidize to a sulphate solution that may contribute to concrete degradation [11].

\section{MATERIALS AND METHODS}

The town covered by the research is located in the West Pomerania province. It is characterized by scattered housing. The tested pumping stations are of local character and cover from several to several dozen inhabitants. This leads to pump stops of a few hours and residual sewage in the pumping station chambers and pressure pipelines. A diagram of the system covered by the research is shown in Fig. 2.The tests were carried out in February 2019.

Samples of corroded concrete were taken from the internal walls of wells at two different heights. First sample ca. $0.5 \mathrm{~m}$ below the ground - close to the manhole. Second sample ca. $1.2 \mathrm{~m}$ below the ground. The well layout with the sampling sites is shown in Fig. 1. The concrete samples were dried and then subjected to microscopic analysis. For comparison, concrete samples from a new sewage well made of $\mathrm{C} 35 / 45$ concrete were also tested.

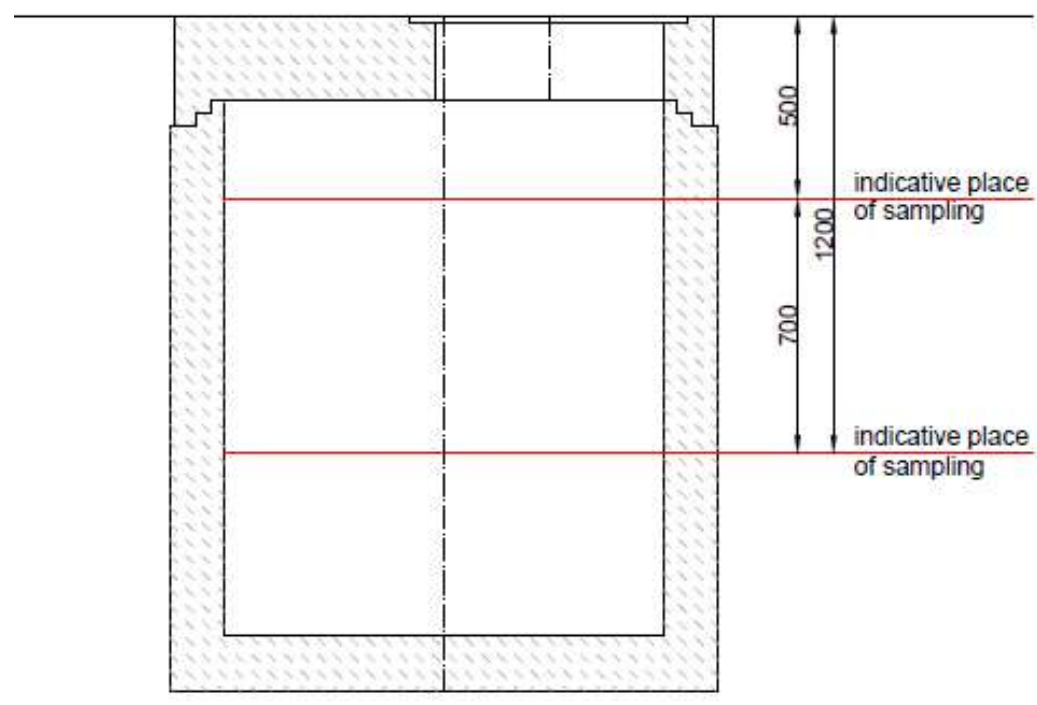

Fig. 1. Places of sampling from the manholes

Gas concentrations in wells were measured with a Draeger X-am 5000 multi-gas detector equipped with EC-Sensor XXS H2S with a measurement range up to $200.00 \mathrm{ppm}$. The measurements were made using an external automatic gas 
suction pump from different depths of the well. In addition, the NH3 concentration (DraegerSensor XXS NH3, measuring range up to $300.00 \mathrm{ppm}$ ) was measured in the air alongside CH4 (DraegerSensor CatEx 125 PR with a measuring range up to $100 \%$ LEL. CH4).

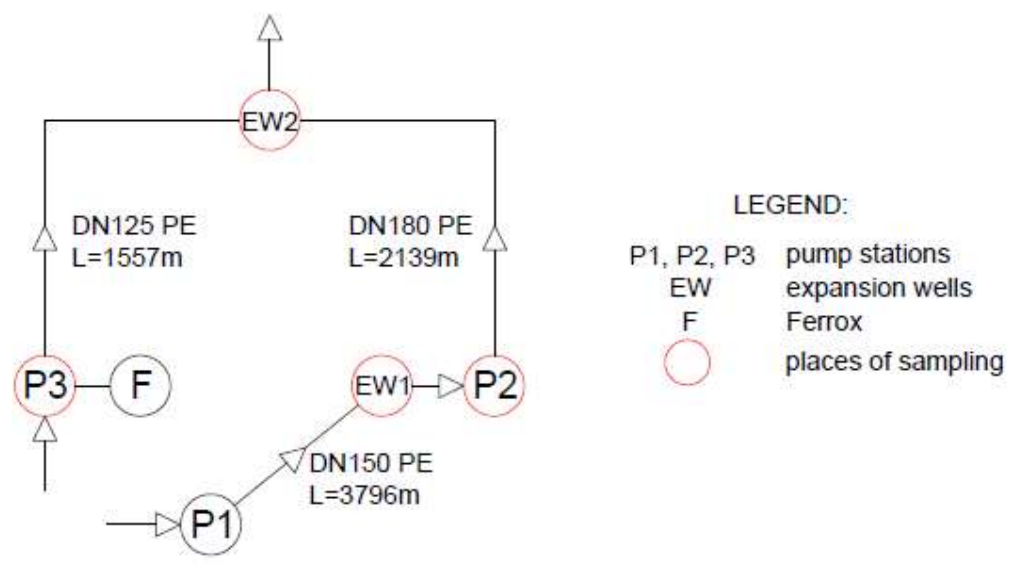

Fig. 2. Scheme of studied system

Scanning electron microscope Hitachi TM 3000 equipped with EDS unit was used in order to observe the elemental concentration spectrum and determine the elemental composition of the analyzed concrete samples. The presented analysis results are the average of some replicates, depends of the sample. The standard deviation were calculated.

\section{RESULTS AND DISCUSSION}

\section{- Concentration of gases}

A measured concentration of gases is shown in table 2. The tests were carried out in the winter season. Random instantaneous measurements were made. High concentrations of hydrogen sulphide (from 0 to over $200 \mathrm{ppm}$ ) and ammonia (from 12 to over $300 \mathrm{ppm}$ ) were observed, which indicates odor problems and possible sulphate corrosion in the system. The EW2 well also showed the presence of methane, which is formed in the process of fermentation in the biofilm and sediments deposited in the sewage system. The high concentration of hydrogen sulphide and the presence of methane mean that there is a significant oxygen deficiency in the pipeline and that the sewage remains in the pipe for a long time. Ferrox was dosed into well P3 to reduce odor concentrations. In the pumping station itself, instantaneous measurements showed no hydrogen sulphide and only $12 \mathrm{ppm}$ of ammonia. Meanwhile, in the expansion well, where 
the sewage from the P3 and P2 pumping stations (where Ferrox was not used), gas concentrations were very high - over 200 ppm. Since significant gas concentrations have been observed in pumping station P2, it is concluded that this system is responsible for the tested concentrations of hydrogen sulphide and ammonia in EW2.

Table 2. Concentration of gases in the manholes [ppm]

\begin{tabular}{|l|l|l|l|l|}
\hline \multirow{2}{*}{ Manhole designation } & \multicolumn{3}{|l|}{ Gases concentration } & Features \\
& of precipitate \\
\cline { 2 - 5 } & $\mathbf{C H}_{4}$ & $\mathbf{H}_{\mathbf{2}} \mathbf{S}$ & $\mathbf{N H}_{\mathbf{3}}$ & white \\
\hline $\mathbf{E W 1}$ & 0 & 65 & 230 & greasy \\
\hline $\mathbf{P 2}$ & 0 & 120 & 250 & friable, white \\
\hline EW2 & 1,1 & $>200^{*}$ & $>300^{*}$ & friable \\
\hline P3** & 0 & 0 & 12 &
\end{tabular}

* above measurement range, which was $200 \mathrm{ppm}$ for hydrogen sulfide and $300 \mathrm{ppm}$ for ammonia

** Ferrox were dosed to P3 pump station

\section{- Microscope analysis - new concret}

Figures 3, 4, 5 show the EDS microscopic analysis for a comparative sample of a new sewage well. Table 3 presents the results of the elemental composition analysis of all tested samples.

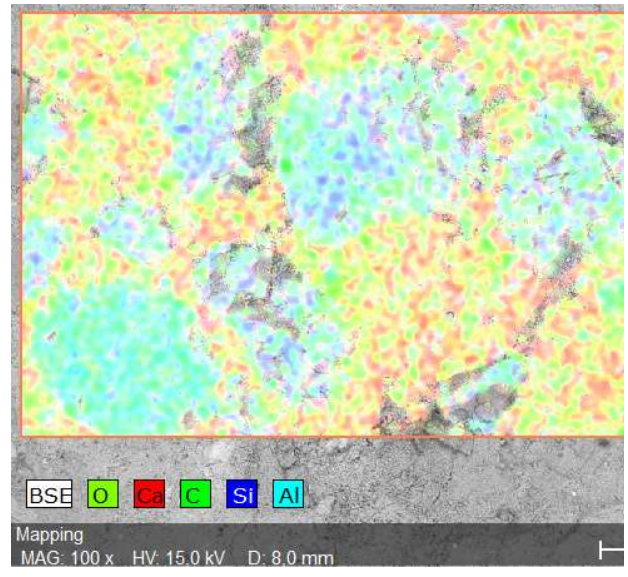

Fig. 3. Map of identified elements

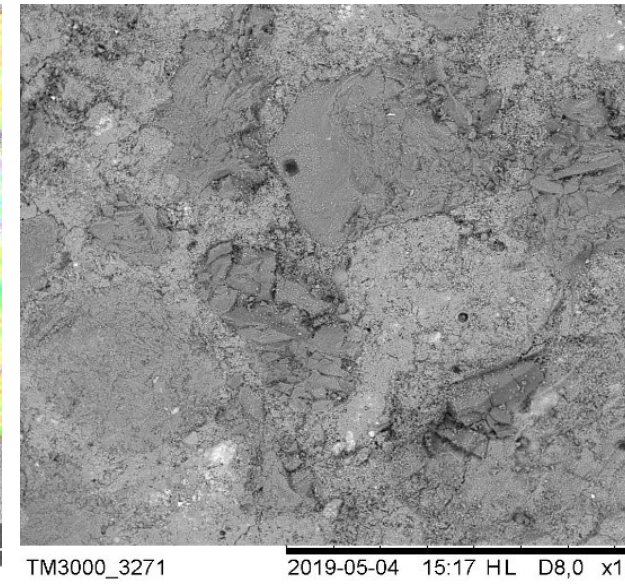

Fig. 4. SEM image of external layer of the concrete, mag. $\mathrm{x} 100$ 


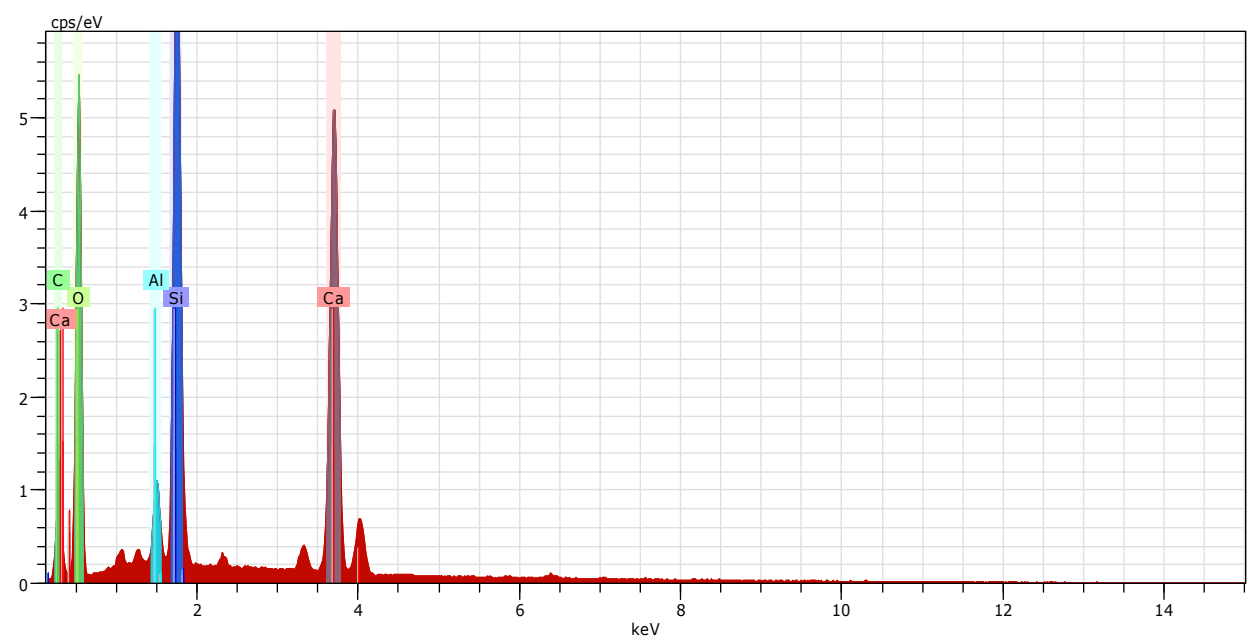

Fig. 5. Energy spectrum of elements identified on sample

The EDS analysis showed that the main component in the tested concrete sample is oxygen (50.43\%), followed by calcium (19.07\%), silicon (14.7\%) and carbon $(10.27 \%)$. Other elements, such as aluminum, potassium, sodium and magnesium, are present in much smaller quantities.

\section{- Microsocpe analysis - concrete from the studied network}

Figures $6,7,8$ present the EDS microscopic analysis for a sample from the EW1 well.

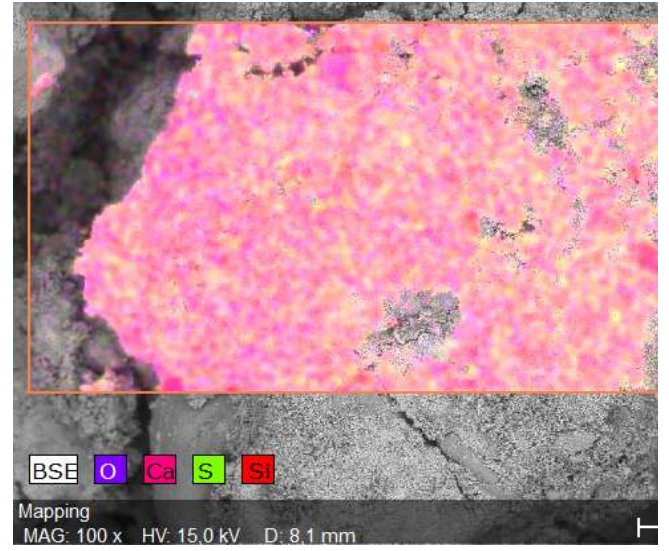

Fig. 6. Map of identified elements

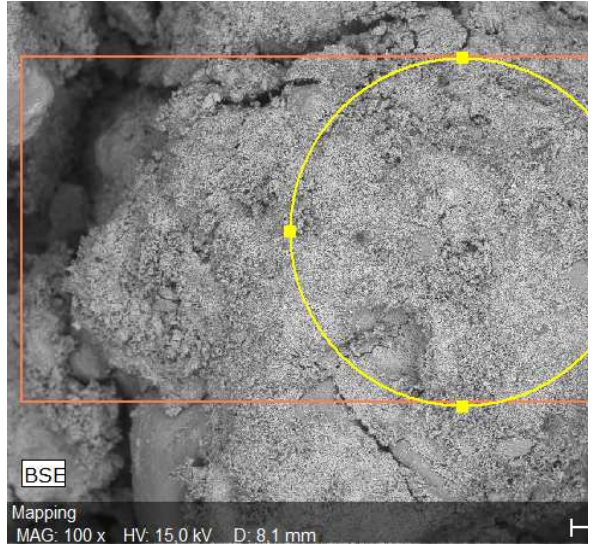

Fig. 7 SEM image of external layer of the concrete, mag. 100x. 


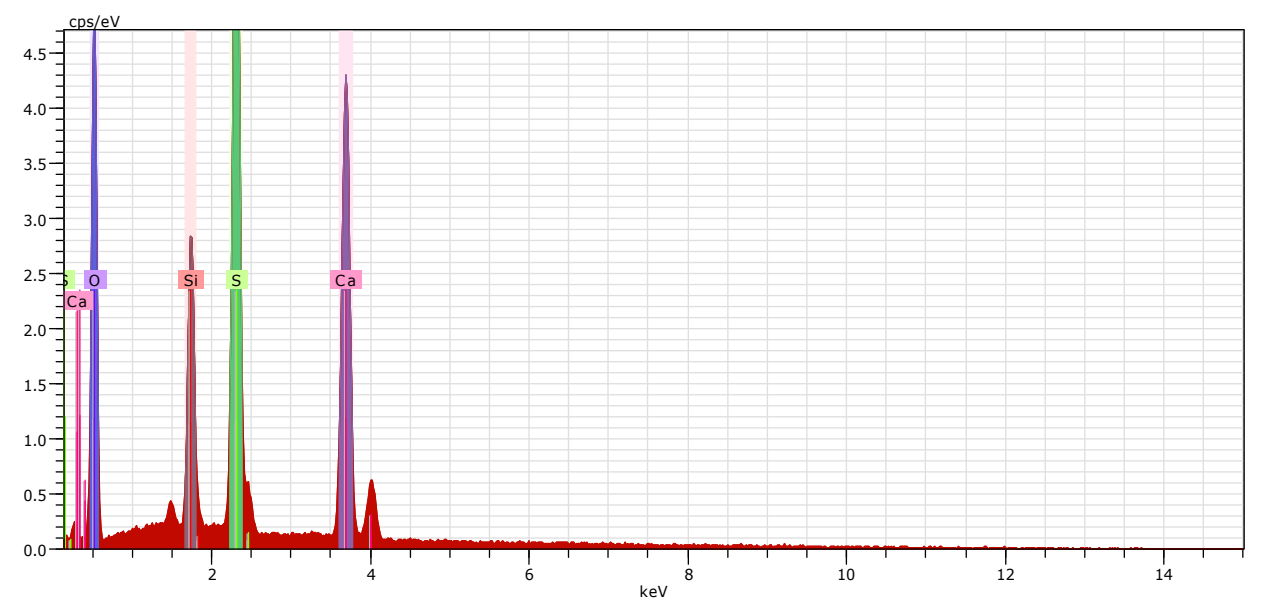

Fig. 8. Energy spectrum of elements identified on sample surface of EW1 manhole

Table 3. Average share of elements in concrete samples at two different well depths [\%]

\begin{tabular}{|l|c|c|c|c|c|c|}
\hline $\begin{array}{l}\text { Manhole } \\
\text { designa- } \\
\text { tion }\end{array}$ & $\begin{array}{c}\text { Depth } \\
{[\mathbf{m}]}\end{array}$ & $\mathbf{O}$ & $\mathbf{C a}$ & $\mathbf{S}$ & $\mathbf{S i}$ & $\mathbf{C}$ \\
\hline \multirow{2}{*}{ EW1 } & 0,5 & 51,9 & 21,4 & 17,9 & 5,5 & 3,3 \\
\cline { 2 - 7 } & 1,2 & $49,75 \pm 0,21$ & $7,2 \pm 5,8$ & $12,35 \pm 0,78$ & $1,5 \pm 0,14$ & $29,2 \pm 5,37$ \\
\hline \multirow{2}{*}{ P3 } & 0,5 & $56,63 \pm 1,74$ & $10,90 \pm 7,95$ & $7,57 \pm 5,25$ & $16,70 \pm 14,56$ & $7,63 \pm 2,35$ \\
\cline { 2 - 7 } & 1,2 & $46,20 \pm 6,61$ & $9,43 \pm 7,56$ & $7,50 \pm 3,98$ & $2,47 \pm 2,42$ & $33,23 \pm 19,91$ \\
\hline \multirow{2}{*}{ EW2 } & 0,5 & $49,8 \pm 1,13$ & $25,5 \pm 3,68$ & $19,65 \pm 0,35$ & $4,95 \pm 2,76$ & $0,1 \pm 0,14$ \\
\cline { 2 - 7 } & 1,2 & $48,9 \pm 2,55$ & $21,65 \pm 1,91$ & $20,85 \pm 1,63$ & $4,55 \pm 1,77$ & $4,1 \pm 1,13$ \\
\hline
\end{tabular}

Measurement results (Table 3) indicate that oxygen has the highest share in all wells at both depths (from $46.20 \%$ to $56.63 \%$ ) and a relatively low variability of results (standard deviation from $0.21 \%$ to $6.61 \%$ ). In the EW1 well, a marked variability in the distribution of elements at different depths was observed. The sample taken $0.5 \mathrm{~m}$ below the ground is characterized by a higher amount of calcium $(21.4 \%$ to $7.2 \%)$ compared to the sample taken $1.2 \mathrm{~m}$ below the ground, with more sulphur (17.9\% to $12.35 \%$ ), a higher amount of silicon (5.5\% to $1.5 \%)$ and much less carbon (3.3\% to $29.2 \%)$. In the $\mathrm{P} 3$ well in the shallow sample, there is more silicon (16.70\% to $2.47 \%$ ) and less carbon ( $7.63 \%$ to $33.23 \%$ ). In each of the studied wells, a greater share of coal occurs at the greater depth of sampling compared to the samples taken at a depth of $0.5 \mathrm{~m}$. 
Table 4. Average percentage participation of elemets on the surface of samples [\%]

\begin{tabular}{|l|c|c|c|c|c|}
\hline \multirow{2}{*}{$\begin{array}{c}\text { Manhole } \\
\text { designation }\end{array}$} & $\mathbf{6}$ & $\mathbf{C a}$ & $\mathbf{S}$ & $\mathbf{S i}$ & $\mathbf{C}$ \\
\cline { 2 - 6 } EW1 & $50,47 \pm 1,25$ & $11,93 \pm 9,17$ & $14,2 \pm 3,25$ & $2,83 \pm 2,31$ & $20,57 \pm 15,43$ \\
\hline P2 & 28,1 & - & 42,9 & 0,4 & 28,7 \\
\hline P3 & $51,42 \pm 7,16$ & $10,17 \pm 6,98$ & $7,53 \pm 4,17$ & $9,58 \pm 12,16$ & $20,43 \pm 18,91$ \\
\hline EW2 & $49,35 \pm 1,69$ & $23,58 \pm 3,27$ & $20,25 \pm 1,18$ & $4,75 \pm 1,91$ & $2,10 \pm 2,40$ \\
\hline $\begin{array}{l}\text { New } \\
\text { manhole }\end{array}$ & $50,43 \pm 1,00$ & $19,07 \pm 7,93$ & - & $14,7 \pm 5,65$ & $10,27 \pm 1,67$ \\
\hline
\end{tabular}

In the wells studied, a high proportion of oxygen (from $28.1 \%$ to $51.42 \%$ ), calcium and sulphur was observed. Sulphur does not occur in the new concrete, while in corroded wells its share ranges from $7.53 \%$ to $42.9 \%$. Silicon also has a significant share (from $0.4 \%$ to $14.7 \%$ ). In the new well, the amount of silicon is higher than in corroded ones $(14.7 \%$ to $4.75 \%, 9.58 \%, 0.4 \%$ and $2.83 \%$ (Table 4). Other elements are present in trace amounts. According to the standard [10] and table 1 [9], sulphur compounds should be expected at a level not exceeding $4.5 \%$ in fresh concrete. No sulphur compounds were found in the tested sample from the new well. Meanwhile, in research by Stryszewska and Stanaszek-Tomal [12] the samples of corrosive sediments contained from $1.35 \%$ to $15.6 \%$ sulphur, while in most trials this value was above $10 \%$. The results presented in Table 3 indicate that in all the samples from corroded wells, the amount of sulphur is greater than $4.5 \%$, and up to even $42.9 \%$.

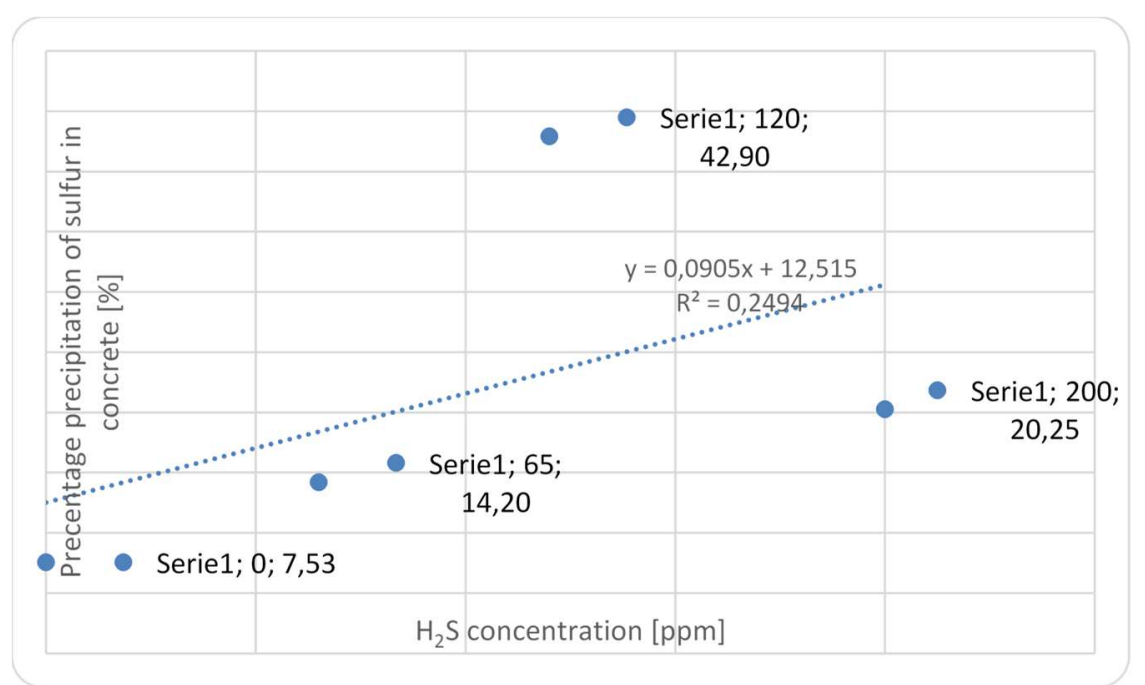

Fig. 9. Correlation between the share of sulphur in the concrete sample and $\mathrm{H}_{2} \mathrm{~S}$ concentration in the air. 
Fig. 9 shows the correlation between the amount of sulphur observed in the concrete samples and the concentration of hydrogen sulphide in the air. It was assumed that the $\mathrm{H}_{2} \mathrm{~S}$ concentration in the EW2 well was $200 \mathrm{ppm}$. For this assumption, the value of the correlation coefficient is approx. 0.5.

\section{CONCLUSIONS}

1. The tests showed clear differences in the elemental composition of concrete samples from the new well and from the existing system. First of all, there are no sulphur compounds in the new well, and the share of sulphur in the examined system ranged from $7.53 \%$ to $42.9 \%$.

2. A weak correlation was found between the amount of sulphur on the concrete surface and the concentration of hydrogen sulphide in the air.

3. A smaller amount of silicon and a larger amount of carbon in corroded wells were observed.

4. A high amount of carbon can be associated with the process of concrete carbonization. A significant amount of sulphur indicates possible reactions of concrete with sulphuric acid, which is associated with strong exposure of well walls to hydrogen sulphide, and consequently causes sulphate corrosion.

5. In P3 well the amount of sulphur is the smallest which can be related to the dosage of Ferrox, which inhibits the formation of hydrogen sulphide.

\section{REFERENCES}

[1] Guangming, J, Jing, S, Keshab, S and Zhingo, Yn 2015. Corrosion and odor management in sewer systems", Curr. Opin. Biotechnol., nr 33, s. 192-197.

[2] „DIN EN 1671 Druckentwässerungssysteme außerhalb von Gebäuden. (Systemy kanalizacyjne ciśnieniowe na zewnątrz budynków)".

[3] „PN-EN 1671: 2001. Zewnętrzne systemy kanalizacji ciśnieniowej”.

[4] Stachowiak, M, Troszczyńska, M and Dymaczewski, Z 2017. „Przeciwdziałanie uciążliwości odorowej w systemach kanalizacji grawitacyjno-tłocznej”, Technol. Wody, nr 6, s. 38-45.

[5] Worona, J 2012. Śmierdzi w kanale. Zagniwanie ścieków w kanalizacji tłocznej", Ochr. Śr., maj nr 5.

[6] Dąbrowski, W 2013. „Pompowanie ścieków - uciążliwości eksploatacyjne”, Rynek Instal., grudzień nr 12, s. 69-73.

[7] O'Connell, M, McNally, C and Richardson, M. G Biochemical attack on concrete in wastewater applications: A state of the art review", Cem. Conrete Compos., nr 32, s. 479-485, 210 n.e. 
[8] Baszkiewicz, J and Kamiński, M 2006. Korozja materiałów. Warszawa: Oficyna Wydawnicza Politechniki Warszawskiej.

[9] Neville, A 2000. Właściwości betonu, 4. wyd. Polski Cement Sp. z o.o..

[10] „PN-EN 197-1 Cement. Część 1: Skład, wymagania i kryteria zgodności dotyczące cementów powszechnego użytku".

[11] Marchand, J, Odler, I and Skalny, J. P 2003. Sulfate Attack on Concrete, Reprint. CRC Press.

[12] Stryszewska, T and Stanaszek-Tomal, E 2017. The degradation of concrete in the presence of domestic sewage", Ochr. Przed Korozja, nr 60 (6), s. $197-$ 200.

[13] Gruener, M 1983. Korozja i ochrona betonu. Warszawa: Arkady.

[14] Zhang, C, Wen, F and Cao, Y 2011. „Progress in Research of Corrosion and Protection by Sulfate-Reducing Bacteria”, Procedia Environ. Sci., nr 10, s. $1177-1182$.

[15] Wells, T, Melchers, R and Bond P 2009. „Factors involved in the long term corrosion of concrete sewers", zaprezentowano na 49th Annual Conference of the Australasian Corrosion Association.

[16] Abdollahi, M and Hosseini, A 2014. „Hydrogen Sulfide”, w Encyclopedia of Toxicology. Third Edition, P. Wexler, Red. Academic Press, s. 971-974.

[17] „Hydrogen Sulfide Corrosion In Wastewater Collection And Treatment Systems", U.S. Environmental Protection Agency, maj 1991.

[18] Hvitved-Jacobsen, T, Jutte, B, Nielsen, P and Jensen, N 1988. Hydrogen Sulphide Control in Municipal Sewers", w Pretreatment in Chemical Water and Wastewater Treatment.

[19] Kane, J 2014. „HYDROGEN SULPHIDE GAS IN SEWERS - THE CHALLENGES OF ODOUR AND CORROSION", zaprezentowano na 39th Annual Queensland Water Industry Operations Conference, Logan, s. $75-81$.

[20] „Odor and Corrosion Control i Sanitary Sewerage Systems and Treatment Plants", U.S. Environmental Protection Agency, 1985.

Editor received the manuscript: 10.05.2019 